\title{
Pheromones control oriental fruit moth and peach twig borer in cling peaches
}

\section{Carolyn Pickel - Janine Hasey Walt Bentley \\ William H. Olson a Joe Grant}

Slow-release pheromone technology can successfully control oriental fruit moth and peach twig borer while eliminating in-season insecticide sprays in cling peaches. In conjunction with a demonstration program, we compared mating disruption for these two pests with standard grower pestcontrol methods in the Sacramento and San Joaquin valleys, and monitored for pest damage, yield and grower costs. While the mating-disruption program was effective in controlling the targeted pests, costs were higher and growers preferred a partial disruption program that included some supplemental late-season insecticide sprays. Subsequently, we developed monitoring methods to determine the need for supplemental sprays. This partial matingdisruption program still costs about $\$ 60$ more per acre than a standard spray program. Predicting efficacy and determining the need for supplement sprays is also more difficult with the partial program than with the pheromone-based control program.

ost insecticides applied to cling 1 peaches target two key insect pests: oriental fruit moth and peach twig borer. Both are lepidopteran pests that infest the fruit as it matures. Broad-spectrum toxic pesticides such as azinphos methyl, permethrin and esfenvalerate are effective in controlling these species. However, they have other problems such as contamination of surface water due to runoff from orchards, field-worker and pesticide ap-

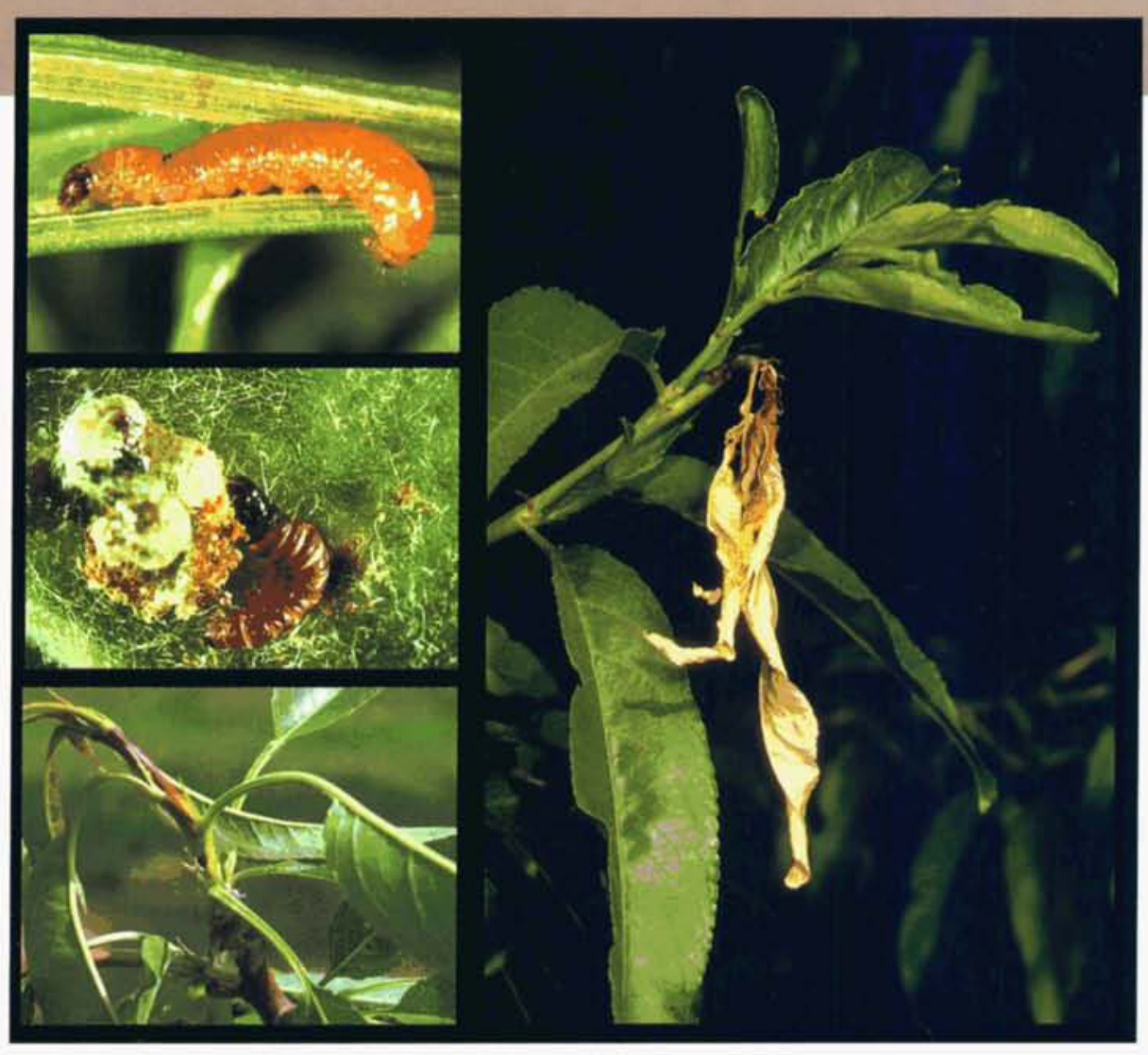

The major pests of cling peaches are oriental fruit moth, upper left, and peach twig borer, left middle. These pests can bore into the terminal of the leaf, lower left, and cause it to wither and die, right. Broad-spectrum insecticides are effective in controlling these species, but can cause other problems such as insect resistance and secondary pest outbreaks. Photos by Jack Kelly Clark.

plicator safety concerns, and the development of pest resistance due to overuse (Barnett 1994). Most in-season insecticides currently used by cling peach growers are disruptive to beneficial arthropods, increasing secondary pest resurgence and often requiring preventative mite sprays.

In 1987, products for managing oriental fruit moth (Grapholitha molesta) utilizing slow-release pheromone technology became commercially available as an alternative to broad-spectrum sprays (Weakley et al. 1987). When orchards are treated with pheromones, the air in the tree canopy is saturated with the synthetic species-specific pheromone used by females to attract males for mating. This technology confuses males, making it difficult for them to locate native females and re- sulting in less mating. Pheromone traps placed in pheromone-treated orchards in 1988 eliminated male flight. Between 1987 and 1995, approximately 6,000 acres were annually treated with pheromones to control oriental fruit moth, representing $22 \%$ of California's 27,000 cling peach acres. Growers with oriental fruit moth populations resistant to azinophos methyl (Guthion) readily adopted this matingdisruption technology. Other growers were reluctant because they still had to spray for peach twig borer (Anarsia lineatella). In 1995, the first commercial peach twig borer product using pheromones became available, allowing further adoption of this technology and decreasing the use of insecticides.

We introduced a pheromone-based 
TABLE 1. Blocks and commercial products participating in the mating-disruption demonstration by county, 1995-1997

\begin{tabular}{|c|c|c|c|c|c|c|c|c|c|c|c|}
\hline \multirow[b]{2}{*}{ County } & \multirow[b]{2}{*}{ Year } & \multirow[b]{2}{*}{ Blocks } & \multirow[b]{2}{*}{ Acres } & \multirow{2}{*}{$\begin{array}{c}\text { Paired } \\
\text { comparisons }\end{array}$} & \multicolumn{3}{|c|}{ OFM* } & \multicolumn{2}{|c|}{ PTB } & \multirow{2}{*}{$\begin{array}{c}\text { Blocks } \\
\text { with Bt } \\
\text { pheromone }\end{array}$} & \multirow{2}{*}{$\begin{array}{c}\text { Partial } \\
\text { program } \\
\text { blocks }\end{array}$} \\
\hline & & & & & $\overline{1 t}$ & C & $\bar{H}$ & $\bar{C}$ & $\mathrm{H}$ & & \\
\hline \multirow[t]{2}{*}{ Butte } & 1995 & 7 & 42 & 1 & 5 & 2 & 0 & 6 & 1 & & \\
\hline & 1996 & 13 & 116 & 0 & 2 & 11 & 0 & 6 & 7 & & \\
\hline \multirow{3}{*}{$\begin{array}{l}\text { Sutter } \\
\text { Yuba }\end{array}$} & 1995 & 14 & 105 & 5 & 0 & 8 & 6 & 8 & 6 & & \\
\hline & 1996 & 12 & 179 & 10 & 9 & 2 & 1 & 2 & 10 & & \\
\hline & 1997 & 19 & 105 & 6 & 4 & 15 & 0 & 16 & 2 & 16 & 6 \\
\hline $\begin{array}{l}\text { San } \\
\text { Joaquin }\end{array}$ & 1996 & 4 & 15 & 4 & 0 & 4 & 0 & 4 & 0 & 0 & 0 \\
\hline \multirow[t]{2}{*}{ Merced } & 1996 & 6 & 48 & 0 & 0 & 5 & 1 & 2 & 1 & 1 & 2 \\
\hline & 1997 & 4 & 27 & 1 & 0 & 0 & 0 & 4 & 0 & 0 & 0 \\
\hline \multirow[t]{2}{*}{ Kings } & 1996 & 7 & 16 & 1 & 0 & 1 & 6 & 4 & 1 & 0 & 2 \\
\hline & 1997 & 2 & 19 & 2 & 0 & 2 & 0 & 2 & 0 & 0 & 0 \\
\hline
\end{tabular}

integrated pest management (IPM) program to cling peach growers in 1995 through on-farm demonstrations. The program -- supported primarily by USDA-ES IPM Smith Lever Funds, the Cling Peach Advisory Board and the California Department of Pesticide Regulation - was designed to determine if pheromone mating disruption of oriental fruit moth and peach twig borer, using commercially available dispensers, provided acceptable control across a range of growing conditions. Another purpose was to develop a monitoring program for identifying secondary pests.

In 1995 and 1996, growers used a complete pheromone-based program for both pests; supplemental sprays were applied only when indicated by monitoring. In 1997, a partial program was developed by growers to incorporate pheromones by making one application of oriental fruit moth and peach twig borer dispensers rather than the two applications necessary for seasonlong control. The partial program was supplemented with planned sprays for later generations of oriental fruit moth before harvest. Many growers preferred this partial program because it minimized costs while still providing good control.

In 1995, 16 cooperators participated with 21 blocks that included 151 acres treated in the Sacramento Valley (Butte, Sutter and Yuba counties). The growers purchased pheromone dispensers for oriental fruit moth, and the project provided field pest monitoring and pheromone dispensers for peach twig borer. Supplemental financial and monitoring support was provided to familiarize growers with pheromone confusion as a pest control program.

In 1996, we expanded the program to the San Joaquin Valley, and federal programs allowed individual growers to recover up to $\$ 3,500$ in pheromoneapplication costs. There were 18 cooperators in 1996 with 25 blocks for a total of 295 acres treated in the Sacramento Valley. The San Joaquin Valley had 10 cooperators with 17 blocks for a total of 79 treated acres in Kings, Merced and San Joaquin counties.

In 1997, the project had 151 acres following the pheromone-based IPM program and 229 acres following the partial program, in six counties with 22 cooperators. Over the 3-year period, the pheromone-based program for oriental fruit moth and peach twig borer was used on 672 acres (table 1).

In 1997, 246 acres were also treated with Bacillus thuringiensis (Bt) during bloom, eliminating the use of a dormant insecticide spray. Previous demonstrations utilizing Bt bloom sprays on peaches and prunes showed control of overwintered peach twig borer as well as reductions in bloom damage by obliquebanded leafroller, fruittree leafroller, green fruitworm and cankerworm (Barnett 1992, 1993).

\section{Mating-disruption program}

Three commercial suppliers (Pacific Biocontrol, Consep and Hercon) produced the pheromone dispensers used in the demonstration project, each with different designs and amounts of pheromone active ingredients. Pacific Biocontrol's Isomate for oriental fruit moth had a recommended application rate of 30 grams active ingredient per acre (ai/acre); Consep's Checkmate applied 19.44 grams ai/acre for oriental fruit moth and 20 or 24 grams ai/acre for peach twig borer; and Hercon's Disrupt applied 27 grams ai/acre for oriental fruit moth and 20 grams ai/acre for peach twig borer. The recommended time between applications varied for each product and we followed manufacturers' guidelines. The three oriental fruit moth products were recommended for reapplication at 90 days, with the peach twig borer products recommended at 60 to 90 days.

When the first pheromoneconfusion product was registered in 1987, the manufacturer recommended application at the historic date of the first moth. This can be 2 to 3 weeks earlier than when the actual first moth is trapped, depending on conditions that year. Delaying the first pheromone application until the first moth is caught extends the activity to later in the season, when insect populations are more damaging. The biofix, which is the first actual moth trapped for the season in a particular orchard, is usually much later in orchards that have previously used pheromones for control. In this study the first application of oriental fruit moth pheromone was typically March 1, and for peach twig borer April 1. Since the fruit moth products and Hercon's peach twig borer product lasted 90 days and the Consep peach twig borer product lasted 60 days (1995), the second application of dispensers for both pests was around June 1 in the Sacramento Valley orchards. Although this reapplication was earlier than the recommended 60 days for peach twig borer dispensers, growers were able to save the cost of an additional application by placing both dispensers at the same time. Growers in Kings and Merced counties applied oriental fruit moth and peach twig borer dispensers separately resulting in four discrete applications (twice for each type). We advised growers to monitor pheromone traps for the first moth caught of 


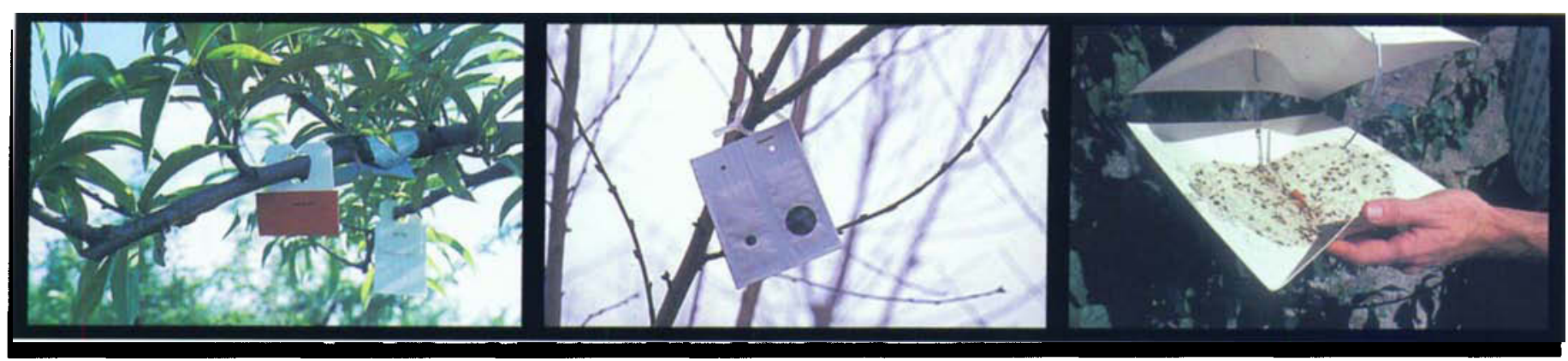

In a demonstration project, cling peach growers in the Sacramento and San Joaquin valleys were introduced to pheromone disruption as a method to control oriental fruit moth and peach twig borer. Several different commercially available products were tested, left and center. Right, A pheromone trap is used to monitor pest levels in the orchard.

each species to determine the application timing.

Growers were also encouraged to place the dispensers in the upper onethird of the tree canopy, since pheromones are heavier than air and sink to the ground. The entrance of larvae causes the terminal shoot growth of plants to wilt and die, which is called a shoot strike. When growers apply pheromone dispensers too low in the tree canopy, a high number of shoot strikes will occur, indicating the need for supplemental sprays.

\section{Field monitoring}

The demonstration blocks ranged from 5 to 38 acres. Because past mating-disruption programs worked better in uniform blocks greater than 10 acres, growers with small orchards were closely monitored to limit fruit damage. However, pheromone confusion can be more successful in small blocks if they are isolated from potential moth sources. The easiest method to evaluate control is with pheromone monitoring traps. If no moths are caught the mating disruption should be working, because males cannot find the traps. We followed weekly pheromone trap catches throughout the season for both pests. In most blocks, a nearby conventional or "standard grower" was monitored for trap-catch comparisons and to pinpoint moth flight for each generation of both species. Traps in disrupted orchards should catch no oriental fruit moth and only a few peach twig borer.

In 1995, some of our matingdisruption blocks sustained shootstrike damage even when no oriental fruit moths were caught in pheromone traps, indicating the need for supplemental sprays. With peach twig borer, however, we could catch low numbers of moths and have no corresponding damage at harvest. For this reason we recommended monitoring shoot strikes to evaluate control during the season. In the Sacramento Valley, shoot-strike counts were taken in each orchard at the end of each oriental fruit moth generation.

It is often difficult to determine which species caused the shoot strikes because the larvae may not be present. To determine the primary species causing strikes, samples should be taken at 500 degree-days from the oriental fruit moth biofix for each generation, when larvae are expected to start causing shoot strikes. In the San Joaquin Valley, shoot strikes were monitored in late May or early June in all locations by counting total strikes per tree from a minimum of five trees in each variety or block. Live larvae were examined and identified from the strikes when possible. Sprays were recommended when an average of three to five strikes per tree was found.

For the harvest sample, 500 peaches in the Sacramento Valley and 1,000 peaches in the San Joaquin Valley were examined from each variety in a block. The fruit were collected in groups of 100 in five or 10 different locations per block. They were evaluated for oriental fruit moth and peach twig borer damage, and live larvae were identified by species. They were also evaluated for secondary pest damage by leafroller, stinkbug and katydid.

We also used traps to monitor for San Jose scale in all locations. Omnivorous leafroller pheromone traps were used in the San Joaquin Valley. Peach blocks next to walnut orchards in the Sacramento Valley were monitored with codling moth pheromone traps, and peaches next to riparian vegetation were monitored for stinkbug. Damage to fruit from secondary pests was scored at harvest.

\section{Trap-catch results}

The three pheromone products caught significantly less than the standard grower method, but were not different from each other (table 2). In the Sacramento Valley, $87 \%$ of the blocks caught two or fewer moths per season, compared with $38 \%$ in the San Joaquin Valley. All the blocks that caught three or more moths in 1995 required a supplemental spray, but one block in 1996 was not sprayed because shoot strikes never reached damaging levels. The decision to spray additional blocks was based on finding more than three to five shoot strikes per

\begin{tabular}{|c|c|c|c|c|c|c|c|c|}
\hline \multirow[b]{3}{*}{ Treatment } & \multicolumn{7}{|c|}{$\begin{array}{l}\text { TABLE 2. Seasonal total oriental fruit moth (OFM) } \\
\text { and peach twig borer (PTB) trap catch, 1995-1997* }\end{array}$} & \multirow[b]{3}{*}{ SD } \\
\hline & \multicolumn{4}{|c|}{ OFMt } & \multicolumn{3}{|c|}{ PTB } & \\
\hline & No. & Range & Mean & SD\$ & No. & Range & Mean & \\
\hline $\begin{array}{l}\text { Standard } \\
\text { grower }\end{array}$ & 20 & $0-455$ & 74.8 & 109.5 & 31 & $2-663$ & 133.0 & \multirow{4}{*}{$\begin{array}{r}173.1 \\
51.6 \\
4.1\end{array}$} \\
\hline Consep & 31 & $0-5$ & 1.45 & 1.53 & 19 & $0-19$ & 16.32 & \\
\hline Hercon & 4 & $0-1$ & 0.25 & 0.5 & 13 & $0-2$ & 3.15 & \\
\hline Isomate & 8 & $0-6$ & 1.0 & 2.1 & & & & \\
\hline \multicolumn{9}{|c|}{$\begin{array}{l}\text { - One-way analysis of variance from all paired comparison blocks. } \\
\text { † Standard grower treatment was significantly different from the three pheromone treatments }(F=4.66, P>0.0055) \\
\text { \$ Standard grower treatment was significantly different from the two pheromone treatments }(F=7.47, P>0.0013) \text {. } \\
\text { 5 Standard deviation. }\end{array}$} \\
\hline
\end{tabular}


tree, rather than solely on trap catches. The standard-grower comparison blocks with high seasonal totals of oriental fruit moth - ranging from 0 to 455 - are the only available measures of potential populations levels in the area (table 2).

Previous research has shown that pheromone confusion does not work as well in orchards with high pest populations. In general, the San Joaquin Valley does not have as high oriental fruit moth populations as the Sacramento Valley, as demonstrated by the lower seasonal totals found in the standard grower treatments. The highest catch in a standard grower's orchard in 1 year was 243 moths in the San Joaquin Valley and 455 moths in the Sacramento Valley. However, in the San Joaquin Valley in 1996 and $1997,61 \%$ of the mating-disruption blocks caught a seasonal total of more than three moths, indicating that mating disruption may not have been adequate and supplemental sprays may be warranted if shoot strikes so indicate.

The use of trap catches to evaluate the effectiveness of mating disruption for peach twig borer is less clear. For oriental fruit moth, field practitioners have felt confident relying on trapcatch shutdown, when the traps fail to catch moths because they cannot find the source of the pheromone. Although field practitioners should not rely solely on trap catches, they are the first indication of potential problems. In our study, we found that trap shutdown is not always linked to adequate control of peach twig borer. The total seasonal trap catch and damage at harvest shows a good correlation $\left(R^{2}=\right.$ 0.81 ) with the mating-disruption orchards combined and a poor correlation $\left(R^{2}=0.11\right)$ with the standard grower orchards (fig. 1). Most of the blocks caught six or fewer peach twig borer during the season. None of the growers had to spray or incurred peach twig borer damage.

Nonetheless, in Merced County one block caught 228 peach twig borer moths in mating-disrupted orchards and subsequently had substantial damage, indicating that mating disruption was no longer occurring. The populations of peach twig borer are

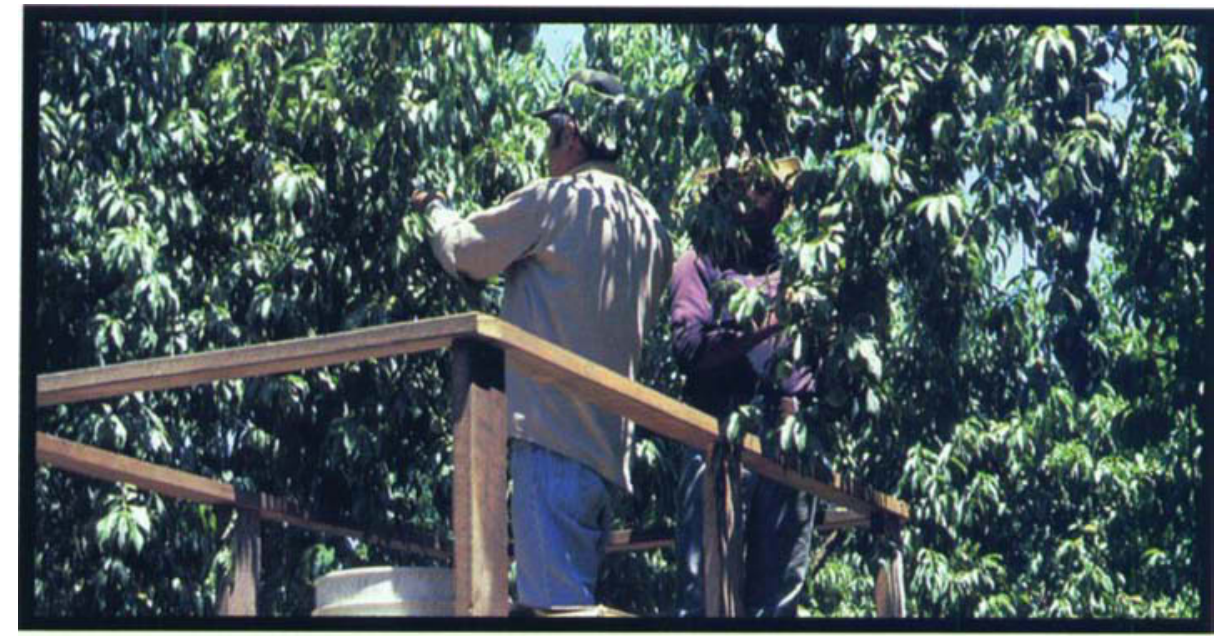

Pheromone dispensers can be placed in the tree using ladders or from a truck, above. Costs for various application methods were measured.

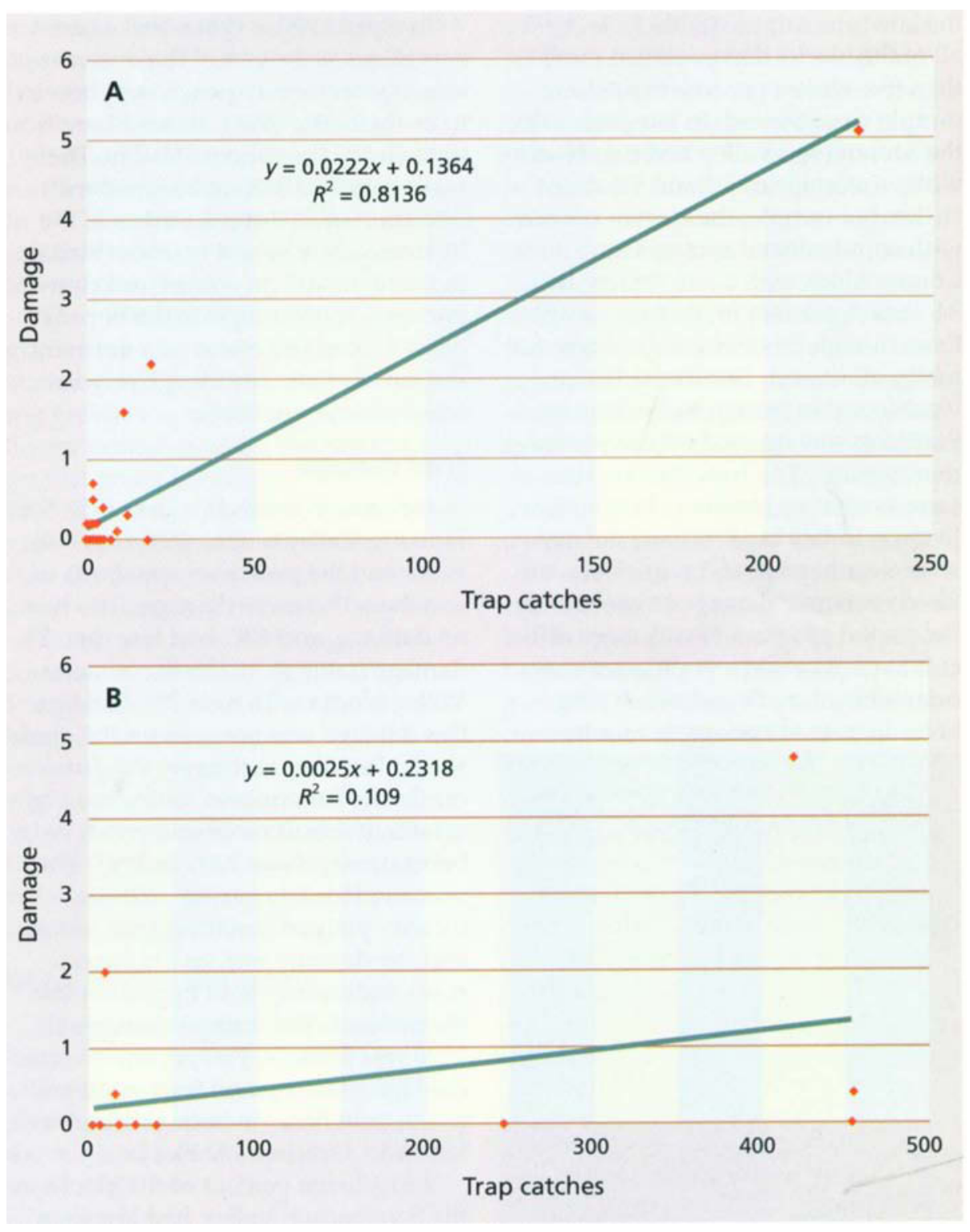

Fig. 1. Correlations from (A) mating-disruption treatments and (B) standardgrower treatments between peach twig borer seasonal total trap catches and damage at harvest. 
much higher in the San Joaquin Valley, especially in Merced County where almond orchards that do not spray for peach twig borer surround many peach orchards. It is more difficult to use pheromone confusion successfully under these conditions. In cases such as Merced County, where untreated almond orchards are located near peaches, the migration of mated moths from the almonds to the peaches occurs and defeats the mating-disruption process.

\section{Shoot-strike results}

In all three years the strike counts for both species were very low until the late June sample (table 3). In 1995, all of the blocks that averaged more than five strikes per tree in the June sample were treated. In late June 1996 , the Sacramento Valley had two blocks with an average of 5.3 and 5.1 shoot strikes per sample; these were treated with supplemental sprays. One Sutter County block with a late variety had 3.8 strikes per tree in the June sample. Even though this block had caught no moths all season, first instar larvae were found in fruit in early August; the block was sprayed to prevent further damage. The June shoot-strike sample was not conducted in the San Joaquin Valley in 1996 since the trees were near harvest and two blocks suffered economic damage at harvest. In the partial program, it was more difficult to predict when populations of oriental fruit moth and peach twig borer increased enough to require

\begin{tabular}{|c|c|c|c|c|}
\hline \multicolumn{5}{|c|}{$\begin{array}{l}\text { TABLE 3. Shoot-strike sample taken at two } \\
\text { sample periods for treatments in mating- } \\
\text { disruption demonstration project, 1995-1997 }\end{array}$} \\
\hline \multirow[b]{2}{*}{ Treatment } & \multicolumn{2}{|c|}{ May samplet } & \multicolumn{2}{|c|}{ June sample‡ } \\
\hline & Mean & SD§ & Mean & SD \\
\hline $\begin{array}{l}\text { Standard } \\
\text { grower }\end{array}$ & 1.8 & 1.1 & 1.1 & 1.7 \\
\hline Consep & 0.3 & 0.5 & 2.2 & 3.7 \\
\hline Hercon & 0.1 & 0.1 & 1.5 & 1.6 \\
\hline Isomate & 0.2 & 0.2 & 0.9 & 1.4 \\
\hline \multicolumn{5}{|c|}{$\begin{array}{l}\text { - One-way analysis of variance from all paired } \\
\text { comparison blocks. }\end{array}$} \\
\hline \multicolumn{5}{|c|}{$\begin{array}{l}\text { Ttatistically significant difference }(F=7.05, P< \\
0.0028) \text { between standard grower and the three } \\
\text { pheromone treatments. }\end{array}$} \\
\hline \multicolumn{5}{|c|}{$\begin{array}{l}\text { No statistically significant difference }(F=0.29, P> \\
0.83) \text { between the standard grower and the three } \\
\text { pheromone treatments. }\end{array}$} \\
\hline \multicolumn{5}{|c|}{ § Standard deviation. } \\
\hline
\end{tabular}

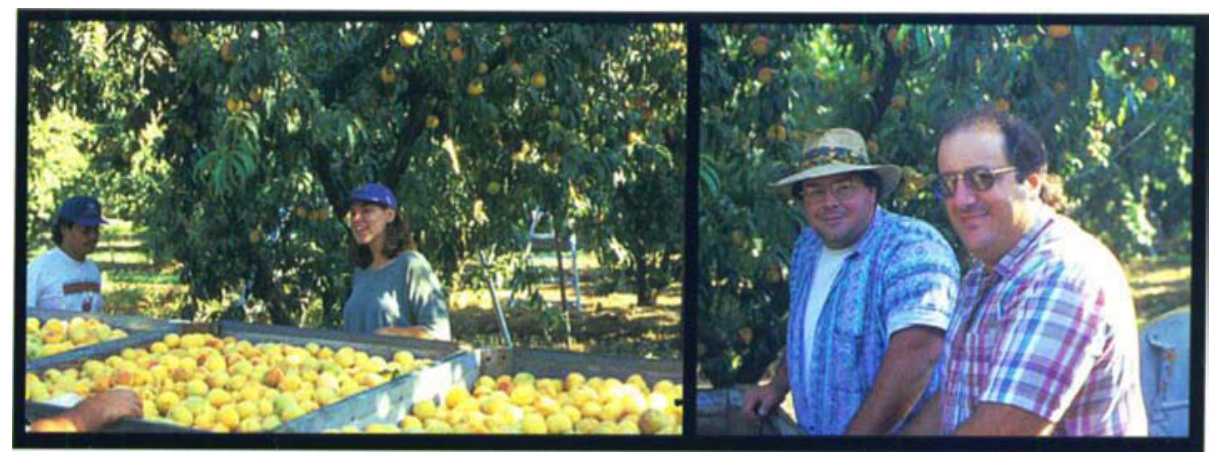

Project manager Cressida Silvers, photo at left, worked with numerous cooperators, including, right, grower Lance Jackson (left) and pest control advisor John Ricomini. Because of higher costs, many of the participating growers preferred a partial program that incorporated pheromone disruption and limited spraying.

spraying, because traps were not tracking moths well enough to determine optimum timing.

In April 1997, a shoot-strike count was taken at the end of the overwintered generation of peach twig borer to evaluate the effect of two Bt applications in the Sacramento Valley. There was a mean of 0.04 and a standard deviation of 0.09 shoot strikes in the Bt-treated blocks and no shoot strikes in the standard-grower paired comparisons, indicating that the Bt program was as successful as a dormant insecticide for controlling overwintered peach twig borer.

\section{Fruit damage}

Infestation levels in most of the Sacramento Valley blocks $(97 \%)$ over all years met the processor standards of less than 3\% larvae damage; $34 \%$ had no damage, and $63 \%$ had less than $3 \%$ damage (table 4). In the Sacramento Valley blocks with over $3 \%$ damage, this damage was not seen on the grade sheet after fruit sorting by the growers. In the Sacramento Valley the highest oriental fruit moth and peach twig borer damage was $2.4 \%$ in 1995 . This was an extra-late variety in Butte County planted in a triangular block, and the damage was on the outside rows, indicating moth migration into the orchard. The highest damage in 1996 was $2.6 \%$. In 1997 , overall worm damage from oriental fruit moth and peach twig borer in both valleys was less than $1.6 \%$ in most blocks.

Sixty-seven percent of the blocks in the San Joaquin Valley had less than $3 \%$ damage at harvest, but four blocks in Merced County exceeded 3\% damage. Oriental fruit moth caused the most damage in the Sacramento Valley, as opposed to peach twig borer in the San Joaquin Valley. Growers in San Joaquin and Kings counties had less damage than in Merced County, where three orchards had peach twig borer damage over acceptable levels $(3.5 \%, 3.6 \%$ and $7.5 \%)$. The block with the highest damage also had 3\% damage from oriental fruit moth. In

Merced County, high peach twig borer pressure came from nearby untreated almond orchards. The average damage due to oriental fruit moth and peach twig borer for the partial pheromone blocks in 1997 was 0.04 with a standard deviation of 0.009 ; this was comparable to the standard-grower paired comparison with mean damage of 0.65 .

\section{Secondary pests}

No damage problems were seen at harvest from either San Jose scale or mites in all years. One block in Sutter County had codling moth damage in three rows next to an unsprayed walnut orchard. The leafroller damage mean was $1.1 \%$ with a standard deviation of 1.5; this was from the summer leafroller generation. Three blocks had more than $3 \%$ damage $(3.2 \%, 3.2 \%$, $7.1 \%$ ), which is the industry grading threshold for rejecting a load. The mean for stinkbug damage was $0.22 \%$, and the standard deviation was 0.47 .

Growers in the San Joaquin Valley had substantial damage from katydid (as high as 3.9\% in a block in Merced County), but the rest had less than $0.3 \%$ katydid damage. This pest has developed into a severe problem in unsprayed pheromone-confusion orchards in the San Joaquin Valley. 


\begin{tabular}{|c|c|c|c|c|c|c|}
\hline \multirow[b]{2}{*}{ Treatment } & \multicolumn{3}{|c|}{ OFMt } & \multicolumn{3}{|c|}{ PTB } \\
\hline & No. & Mean & SD & No. & Mean & SD \\
\hline \multicolumn{5}{|l|}{ Standard } & 0.7 & 1.3 \\
\hline Consep & 13 & 0.6 & 0.9 & 14 & 0.5 & 1.3 \\
\hline Hercon & 3 & 0.2 & 0.2 & 13 & 0.2 & 0.4 \\
\hline Isomate & 6 & 0.0 & 0.0 & $-\S$ & - & - \\
\hline \multicolumn{7}{|c|}{$\begin{array}{l}\text { No statistically significant difference for mean OFM damage between } \\
\text { treatments }(F=0.66 \text { and } P>558) \text {. }\end{array}$} \\
\hline \multicolumn{7}{|c|}{$\begin{array}{l}\text { No statistically significant difference for mean PTB damage between } \\
\text { treatments }(F=0.59 \text { and } P>0.56) \text {. }\end{array}$} \\
\hline \multicolumn{7}{|c|}{ § No data. Isomate does not make a PTB disruptant product. } \\
\hline
\end{tabular}

\begin{tabular}{|c|c|c|c|}
\hline Year & 1995 & 1996 & 1997 \\
\hline Number of growers & 11 & 20 & 9 \\
\hline OFM pheromone* & 96.60 & 92.12 & 90.20 \\
\hline PTB pheromone* & 115.00 & 101.56 & 109.76 \\
\hline Application costs & 50.31 & 37.90 & 18.57 \\
\hline Total costs & 243.00 & 231.58 & 218.53 \\
\hline Partial (OFM + PTB + 1 spray) + & - & - & 158.93 \\
\hline Partial (OFM + PTB + 2 sprays) + & - & - & 182.18 \\
\hline Standard grower & 110.07 & 109.00 & 93.48 \\
\hline
\end{tabular}

Katydid populations increase in the spring and may feed on the fruit from May through August. They can be monitored using a beating tray or sweep net, or by simply looking for feeding damage on fruit.

\section{Economic analysis}

We also conducted an economic analysis of grower costs in the Sacramento Valley from 1995 to 1997 (table 5). At the end of each season, pheromone dispenser costs, application methods and application costs were collected from 11 cooperators in 1995 , 20 in 1996 and nine in 1997. The average dispenser cost per acre for two oriental fruit moth applications decreased from $\$ 96.60$ in 1995 to $\$ 90.60$ in 1997 . The average dispenser cost per acre for two peach twig borer applications declined from $\$ 115.00$ to $\$ 101.56$ over the 3-year period; the price of pheromone dispensers for all four applications dropped $\$ 24.47$ from 1995 to 1997. According to suppliers, pheromone dispenser costs have remained stable since 1997.

We also tracked the amount of labor needed for various pheromoneapplication methods, and the costs incurred. One method is to move individual ladders through the orchard to place the dispensers in the tree; small ladders are easier to carry and move, requiring less time. In all 3 years, ladders were the most expensive application method, although using small ladders cost much less. Growers were able to lower the cost further by using specially designed poles to apply the dispensers from the ground. Application from a tractorpulled trailer was the best method and the least expensive - for getting dispensers high in trees; workers ride in a trailer and place the dispensers from a platform. For most application methods, excluding ladders, the average cost was $\$ 37.90$ per acre for the season. Application cost plus the cost of pheromone was $\$ 243$ per acre in 1995 and $\$ 231.58$ per acre in 1996 . This further decreased to $\$ 218.53$ per acre in 1997 because growers began utilizing methods that allowed them to lower labor costs.

The costs of the pheromone program were also compared with the standard spray programs of participating growers in all three years. Over the 3-year period costs for the standard grower program ranged from $\$ 93.45$ to $\$ 110.07$ per acre. By 1997 , the standard grower program was still \$125.05 less than the complete pheromone program, enough of a difference to prevent growers from adopting it. The costs for the partial program were $\$ 59.60$ lower per acre than the seasonlong pheromone program, and the total number of sprays is reduced compared with the standard grower. (Nonetheless, there is current evidence that spray programs are beginning to fail due to the development of pest resistance [unpublished data].)

\section{Using mating disruption}

Growers and pest control advisors should be aware of the grams of active-ingredient load rates for each pheromone dispenser product and use the one best suited to pest population levels in the block. They should check labels each year, follow the manufacturers' recommendation and know the pheromone application rate of each product. Based on our results, we rec- ommend that growers use products with higher grams per acre when they first start a mating-disruption program. After several years, oriental fruit moth populations will be reduced, and some growers decrease the number of dispensers per acre. However, research has not yet determined how many years it takes to lower pest populations enough to reduce pheromone application rates. Field experience shows varied results depending on how high the population is and the potential for pest migration from surrounding orchards. Growers should be prepared at historic date of the first moth so that they can quickly make applications once the first moth is caught in standard pheromone-baited sticky traps.

Supplemental spraying can be a necessary part of using pheromone technology if resident moth populations are too high. However, over a period of years overall pest populations should drop and additional sprays may not be required. Growers starting a mating-disruption program will have different population levels of oriental fruit moth and peach twig borer in their orchards and different population sources from neighboring orchards. Monitoring is important to determine when supplemental sprays are necessary. If oriental fruit moth or peach twig borer is trapped, growers should monitor shoot strikes to determine the need for supplemental sprays. Blocks typically reached the treatment threshold at the June shootstrike sample on late-season varieties. Cling peach varieties harvested in $\mathrm{Au}$ gust are exposed to additional generations of both oriental fruit moth and 


\section{PHEROMONES - continued from previous page}

peach twig borer, making mating disruption more difficult in these orchards.

Growers using mating disruption should be aware of potential pest populations bordering areas where they use pheromone-confusion technology. Damage in most blocks was linked to orchards with high oriental fruit moth and peach twig borer populations nearby. Growers in these situations may have to spray the edges of the orchard. This is especially true in peach orchards that lie near almond orchards, such as in Merced County.

Other costs associated with spraying, such as worker safety measures, should be considered in cost comparisons. For some growers, the benefits of a less hazardous workplace, pesticide reduction, no drift and less machinery maintenance, plus being able to irrigate and thin as needed, are worth the extra cost of the season-long mating-disruption program. This project showed that mating disruption is an effective alternative to conventional pest control methods. If the overall cost of pheromone dispensers decreases and growers lose currently registered less-expensive pesticides, we expect more peach growers to adopt pheromone confusion.
C. Pickel is Area IPM Advisor, Sacramento Valley; J. Hasey is Farm Advisor, Sutter and Yuba counties; W. Bentley is IPM Entomologist, Kearney Agricultural Center; W.H. Olson is Farm Advisor, Butte County; and J. Grant is Farm Advisor, San Joaquin County. The authors acknowledge Bob Beede, Maxwell Norton, Roger Duncan, Nadeem Shawareb, Cressida Silvers and Lana Osgood for their assistance on this project, and product donations from Abbott Laboratories, Consep and Hercon. We thank our funding sources, including the USDA-ES Smith Lever IPM project, California Cling Peach Advisory Board, EPA Environmental Stewardship Program, Farm Service Agency SP-53 and California Department of Pesticide Regulation.

\section{References}

Barnett WW. 1992. Managing Peach Twig Borer with Bacillus thuringiensis. California Prune Board research report. p 68-82.

Barnett WW. 1993. Managing Peach Twig Borer with Bacillus thuringiensis. Cling Peach Advisory Board and California Tree Fruit Agreement research report. p 1-18.

Barnett WW, Pinto C. 1994. Survey of Azinphosmethyl Resistance in Oriental Fruit Moth. Cling Peach Advisory Board research report. $2 \mathrm{p}$.

Weakley CV, Kirsch PA, Rice RE. 1987. Control of oriental fruit moth by mating disruption. Cal Ag 41(5-6):7-8.
Visit California Agriculture on the Web: http://danr.ucop.edu/calag/

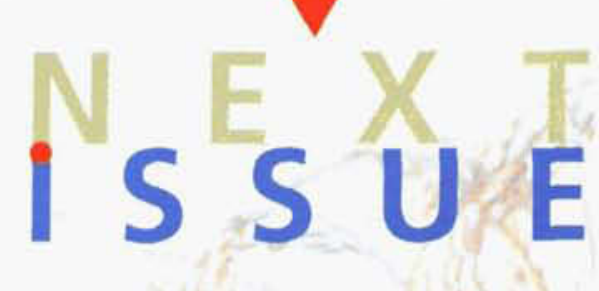

Rice irrigation and salinity

Rice is one of the most sensitive crops to salinity. In the next issue of California Agriculture, research by UC scientists reveals that rice is even more salt-sensitive than current water management guidelines suggest, with yields suffering as a result.

Also:

- Diabetes awareness among Latino adults

- Grapevine leafroll disease and mealybugs

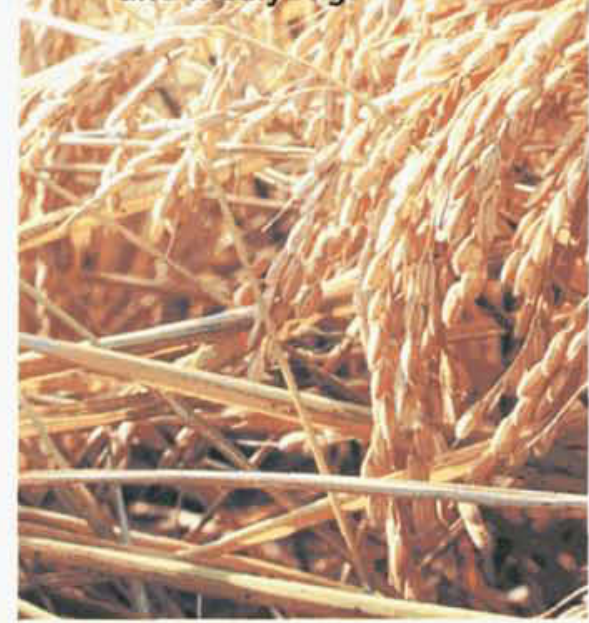

